\title{
Equine infectious anemia in carthorses from urban areas of southern Brazil
}

\section{Anemia infecciosa equina em cavalos carroceiros de áreas urbanas do sul do Brasil}

\author{
João Henrique Perotta ${ }^{1}$; Eliana Monteforte Cassaro Villalobos ${ }^{2}$; \\ Maria do Carmo Custódio de Souza Hunold Lara²; Elenice Maria Sequetin Cunha ${ }^{2}$; \\ Ivan Deconto ${ }^{1}$; Peterson Triches Dornbusch ${ }^{1}$; Thállitha Samih Wischral Jayme Vieira \\ José Edivaldo Bonacim4; Rafael Felipe da Costa Vieira'; Alexander Welker Biondo'; \\ Ivan Roque Barros Filho ${ }^{1 *}$
}

\begin{abstract}
Equine infectious anemia (EIA) is an infectious viral disease caused by a Lentivirus, which affects equids worldwide. The disease has no currently treatment and euthanasia of infected animals is mandatory by the Brazilian Ministry of Agriculture, Livestock and Supply (MAPA) as basis for disease control. Carthorses are used to move daily throughout the cities with their owners to collect recycling materials. Considering the socio-economic importance of this group of horses, the aim of this study was to determine the infection rate of EIA virus in carthorses from urban areas of Curitiba and surroundings. The detection of anti-EIA virus antibodies was performed by the agar gel immunodiffusion test (AGID). One out of 97 (1.03\%) horse was positive for EIA.

Active surveillance programs are crucial for monitoring, prevention and control of infectious diseases, particularly in carthorses, which may act as disseminators of pathogens.
\end{abstract}

Key words: AGID, carthorses, EIA, equids, horses

\section{Resumo}

A anemia infecciosa equina (AIE) é uma doença infecciosa causada por um Lentivírus, acometendo equídeos em todo o mundo. Esta doença não possui tratamento e a eutanásia dos animais infectados é obrigatória pelo Ministério da Agricultura, Pecuária e Abastecimento (MAPA) como base para o controle da doença. Os cavalos carroceiros são utilizados diariamente pelos seus proprietários na coleta de materiais recicláveis nas cidades. Considerando a importância socioeconômica deste grupo de cavalos, o objetivo deste estudo foi determinar a taxa de infecção pelo vírus da AIE em cavalos carroceiros de áreas urbanas de Curitiba e região metropolitana. A detecção de anticorpos anti-AIE foi realizada pelo teste de imunodifusão em ágar gel (IDGA). Apenas 1 de um total de $97(1,03 \%)$ cavalos foi positivo para AIE. Programas de vigilância ativa são cruciais para o monitoramento, prevenção

${ }^{1}$ Profs. Drs., Dept ${ }^{\circ}$ de Medicina Veterinária, Universidade Federal do Paraná, UFPR, Curitiba, PR, Brasil. E-mail: perotta@ufpr. br; deconto@ufpr.br; petriches@gmail.com; rvieira@ufpr.br; abiondo@ufpr.br; ivanbarf@ufpr.br*

${ }^{2}$ Pesquisadores, Laboratório de Raiva e Encefalites Virais, Instituto Biológico, São Paulo, Brasil. E-mail: villalobos@biologico. sp.gov.br; lara@biologico.sp.gov.br; cunha@biologico.sp.gov.br

3 Discente do Curso de Doutorado do Programa de Pós-Graduação em Ciência Animal, Universidade Estadual de Londrina, UEL, Londrina, PR, Brasil. E-mail: vieiratsjw@gmail.com

${ }^{4}$ Médico Veterinário, Centro de Controle de Zoonoses, São José dos Pinhais, PR, Brasil. E-mail: jbonacim@hotmail.com

* Author for correspondence 
e controle de doenças infecciosas, particularmente em cavalos carroceiros que podem atuar como disseminadores de patógenos.

Palavras-chave: AIE, carroceiros, cavalos, equídeos, IDGA

Equine infectious anemia (EIA) is an infectious viral disease caused by an equid-specific Lentivirus of the Retroviridae family, which affects equids worldwide (MEALEY, 2007). EIA virus is transmitted through the blood from infected to susceptible horses, either by blood-feeding insects (mainly Stomoxys calcitrans and Tabanus sp.), vertical transmission in uterus or at parturition, or by contaminated fomites (MEALEY, 2007). Horses usually recover from either acute or chronic clinical disease but remain life-long carriers of the virus (SELLON et al., 1994); therefore, they may introduce this organism into disease free-areas.

The Brazilian National Program of Equine Health has established the identification of EIA virus infection by the agar gel immunodiffusion test (AGID), with seropositive horses either euthanized or placed in quarantine as basis for disease control (BRASIL, 2004). Based on national census, the EIA prevalence is approximately $3 \%$, however the EIA status remains unknown for most horses in Brazil (BRASIL, 1998).

Curitiba and surroundings, Paraná State, southern Brazil, is included in an extension project entitled 'CartHorses'. The project consists of activities for diagnosis, prevention and control of zoonotic diseases. Owners use carthorses to pulled carts daily throughout the cities to collect recycling materials. According to the City Center of Disease Control, Curitiba has approximately 1,500 carthorses. Considering the social-economic importance and the lack of information regarding this virus in horses from urban areas of Paraná State, the aim of this study was to determine the infection rate of EIA virus in carthorses attended by the CartHorse program.

The Ethics Committee in Animal Experimentation and Animal Welfare at the
Universidade Federal do Paraná (protocol number 027/10), Paraná State, Brazil approved this study. A convenient blood sampling was performed from 97 apparently healthy carthorses from different breeds, age, and gender, from urban areas of Curitiba City ( $\left.25^{\circ} 25^{\prime} 47^{\prime} \mathrm{S} 49^{\circ} 16^{\prime} 19^{\prime} \mathrm{O}\right)$ and surroundings. Blood samples were collected from April 2005 to June 2006 by venipuncture of jugular vein using sterile tubes without anticoagulant. The samples were then centrifuged at $1500 \times \mathrm{g}$ for $5 \mathrm{~min}$, and the serum was separated and stored at $-20{ }^{\circ} \mathrm{C}$ until serological analysis.

The detection of anti-EIA antibodies was performed by a commercialAGID (Immunodiffusion Kit Test, EIA antigen and standard serum - Bruch Laboratory, São Paulo, BR), according to the manufacturer's instructions, which is officially adopted by the Brazilian Ministry of Agriculture, Livestock and Supply (MAPA) for EIA diagnosis (BRASIL, 2004).

In the present study, anti-EIA antibodies were found in $1 / 97(1.03 \%)$ horse sample tested. Our findings were similar to those found in horses from Rio de Janeiro (0.74\%) (MARTINS et al., 2005). Seroprevalence rates of EIA in horses from Brazil and other Latin American countries varies from 0 to $33.6 \%$ using the same commercial test (SILVA et al., 1999; SANTOS et al., 2001; HEINEMANN et al., 2002; JACOBO et al., 2003; ALMEIDA et al., 2006; BORGES et al., 2013; CUTOLO et al., 2014; TAVARES et al., 2014). The differences in the seroprevalence of the EIA may be due to climate variation and environmental factors.

Previous studies have shown that the population dynamics of the vectors influences the EIA infection level, since horse flies (Tabanidae) return to the same animal when feed is interrupted, and to the near horse when less than 50 meters apart (BARROS; 
FOIL, 2007). Curitiba City is an international model for sustainable development (AMSTRONG, 2002). Its efficient garbage program promotes an adverse scenario for tabanids, which may explain the low EIA prevalence found in our study. In addition, iatrogenic transmission by contaminated blood through syringes or needles is unlikely since carthorses hardly receive vaccines or medication, and even when the owners vaccine their horses, few horses living together may prevent animal-toanimal transmission.

Environmental and animal policies are critical for prevention and control of infectious diseases. Considering that carthorses move daily throughout the city the dissemination of pathogens, in this case EIA virus, may be increased without active surveillance programs.

\section{Acknowledgments}

The authors are grateful to Zoonosis Control Centers at São José dos Pinhais and Curitiba City for the help with handling and sampling of horses.

\section{References}

ALMEIDA, V. M.A.; GONÇALVES, V. S. P.; MARTINS, M. F.; HADDAD, J. P. A.; DIAS, R. A.; LEITE, R. C.; REIS, J. K. P. Anemia infecciosa equina: prevalência em equídeos de serviço em Minas Gerais. Arquivo Brasileiro de Medicina Veterinária e Zootecnia, Belo Horizonte, v. 58, n. 2, p. 141-148, 2006.

AMSTRONG, M. Curitiba, orienting urban planning to sustainability. International Council for Local Environmental Initiatives Case Study No. 77, 2002. Available at: $<$ http://www.iclei.org.br/polics/CD/P2 4 Estudos\%20de\%20Caso/1_Planejamento\%20Urbano/ PDF106_EC77_Curitiba_ing.PDF>. Accessed at: 23 may 2015.

BARROS, A. T. M.; FOIL, L. D. The influence of distance on movement of tabanids (Diptera: Tabanidae) between horses. Veterinary Parasitology, Amsterdam, v. 144, n. 3-4, p. 380-384, 2007.

BORGES, A. M.; SILVA, L. G.; NOGUEIRA, A. C.; SEGRI, N. J.; FERREIRA, F.; WILTER, R.; AGUIAR, D.M. Prevalence and risk factors for equine infectious anemia in Poconé municipality, northern Brazilian Pantanal. Research in Veterinary Science, London, v. 95, n. 1, p. 76-81, 2013.

BRASIL. Ministério da Agricultura, Pecuária e Abastecimento. Secretaria de Defesa Agropecuária. Departamento de Defesa Sanitária Animal. Boletim de defesa sanitária animal. Brasília: Ministério da Agricultura, 1998. 113 p.

Ministério da Agricultura, Pecuária e Abastecimento. Secretaria de Defesa Agropecuária. Departamento de Defesa Sanitária Animal. Plano Nacional de controle e erradicação da anemia infecciosa equina. Instrução Normativa $\mathrm{N}^{\circ}$ 45, de 15 de junho de 2004.

CUTOLO,A.A.; GONÇALVES, V.L.N.; CORREZOLA, L. M.; GUNNEWIEK, M. F. K. Anemia infecciosa equina em equídeos de área urbana do munícipio de Monte Mor, região metropolitana de Campinas, Estado de São Paulo, Brasil. Semina: Ciências Agrárias, Londrina, v. 35, n. 3, p. 1377-1382, 2014.

HEINEMANN, M. B.; CORTEZ, A.; SOUZA, M. C. C.; GOTTI, T.; FERREIRA, F.; HOMEN, V. S. F.; FERREIRANETO, J. S.; SOARES, R. M.; SAKAMOTO, S. M.; CUNHA, E. M. S.; RICHTZENHAIN, L. J. Seroprevalência da anemia infecciosa equina, da arterite viral dos equinos e do aborto viral equino no município de Uruará, PA, Brasil. Brazilian Journal of Veterinary Research and Animal Science, São Paulo, v. 39, n. 1, p. 50-53, 2002.

JACOBO, R. A.; STORANI, C. A.; CIPOLINI, M. F.; STAMATTI, G. M.; MIRANDA, A. O.; CARDOZO, R. O.; MARTÍNEZ, D. E.; DANSEY, M. B. Seroprevalencia de anemia infecciosa equina em La Provincia de corrientes, período 2001-2002. Comunicaciones Cientificas y Tecnológicas, Corrientes, v. 1, 2003. Disponible en:: <http://www.unne.edu.ar/Web/cyt/ cyt/2003/comunicaciones/04-Veterinarias/V-001.pdf>. Consultado el: 10 fev. 2014.

MARTINS, A. V.; PARREIRA, F. L.; BORGES, C. H. P.; MACHADO, E. D. Anemia infecciosa equina no município de Teresópolis e regiões limítrofes - RJ, no período de 1993 a 2003. Revista Universidade Rural Série Ciências da Vida, Seropédica, v. 25, p. 87-88, 2005. Suplemento.

MEALEY, R. Equine infectious anemia. In: SELLON, D. C.; LONG, M. T. Equine infectious diseases. Saint Louis: Saunders Elsevier, 2007. p. 213-219.

SANTOS, R. M. L.; REIS, J. K. P.; SANTOS, F. G. A.; OLIVEIRA, I. C. S. Frequência de anemia infecciosa em equinos no Acre, 1986 a 1996. Arquivo Brasileiro de Medicina Veterinária e Zootecnia, Belo Horizonte, v. 53, n. 3, p. 310-315, 2001. 
SELLON, D. C.; FULLER, F. J.; McGUIRRE, T. C. The immunopathogenesis of equine infectious anemia virus. Virus Research, Amsterdam, v. 32, n. 2, p. 111-138, 1994.

SILVA, R. A. M. S.; DÁVILA, A. M. R.; IVERSSON, L. B.; ABREU, U. G. P. Equine viral diseases in the Pantanal, Brazil. studies carried out from 1990 to 1995. Revue d'Élevage et de Médecine Vétérinarire des Pays Tropicaux, Montpellier, v. 52, n. 1, p. 9-12, 1999.
TAVARES, T. R.; FIRAS, N. C.; MALDOS, P. C. W.; TEIXEIRA, C.; PARANHOS, N. T. Anemia infecciosa equina em equídeos removidos pelo centro de controle de zoonoses de São Paulo entre 2009-2013. In: CONFERÊNCIA ANUAL DA ABRAVEQ, 15., 2014, Campos do Jordão. Anais... Campos do Jordão: [s.n.], 2014. p. 160-161. 